\title{
Foreign Direct Investment, Financial Development and Economic Growth
}

\section{Evidence from Saudi Arabia}

\author{
Najeeb Muhammad Nasir ${ }^{1}$, Mohammed Ziaur $\operatorname{Rehman}^{1} \&$ Nasir Ali ${ }^{1}$ \\ ${ }^{1}$ Department of Finance, King Saud University, Riyadh, Saudi Arabia \\ Correspondence: Mohammed Ziaur Rehman, Department of Finance, King Saud University, Riyadh, Saudi Arabia.
}

Received: October 7, 2017

Accepted: October 17, 2017

Online Published: October 26, 2017

doi:10.5430/ijfr.v8n4p228

URL: https://doi.org/10.5430/ijfr.v8n4p228

\begin{abstract}
This study is an effort to explain and establish a relationship among foreign direct investment, financial development and economic growth in Saudi Arabian context for the period of 1970 to 2015 by employing Vector Auto Regression (VAR) and modified Granger Casualty Models. The result of Johansen co-integration test illustrates that no long run co-integration can be established among the variables. VAR has established a link between economic growth, financial development and foreign direct investment. The Granger causality test also confirms that economic growth causes foreign direct investment and financial development which is a unidirectional causality running from economic growth towards foreign direct investment and financial development. No significant causality can be observed empirically between foreign direct investment and financial development. This feature can be attributed to the fact that Saudi Arabian economy is still heavily dependent on its oil resources which is the driving force behind growth. Impulse Response Function has been utilized in order to observe the response to the shocks among the variables.
\end{abstract}

Keywords: Saudi Arabia, foreign direct investment, financial development, economic growth, VAR

\section{Introduction and Theoretical Background}

In order to substantiate the growth of economy, countries have kicked off multiple set of reformation in the economies. Studies manifest that economies incorporating growth led programs stimulates the economic liberalization which leads to the inflows of foreign direct investment. The FDI usher in multi facets developments which sequentially spur the growth of the countries (Balasubramanyam et al., 1996; Agarwal, 2001). In comparison to other modes of capital flows, the attributes of FDI inflows are unwavering and assists the economy in multiples ways. FDI inflows, in its multifarious dimensions influence the economic welfare, growth and development of the recipient economy (WIR93 \&99). FDI reveals itself in the shape of TNCs, which link with the local economy and set up backward and forward linkage in the economy. Further it creates spillover advantages for the local firms in terms of enhancing the efficiency. Likewise; there is promising opportunities in term of employment opportunities.

In this line, this paper aims to unfold the linkage among the foreign direct investment, financial development and economic growth in the Saudi Arabian economy. Since the joining of the World Trade Organization in 2005, the country has advanced the investment milieu in order to unfold the trade and investment. US, Japan, France and the leading gulf economies have led the investment influx in the Saudi economy. Real estate, petrochemicals and contracting sector are the leading arenas that have garnered the foreign direct investment in the country. The country promises to be an ideal destination for foreign direct investment on account of having minimum energy prices. Further the shift of business related capital and gains to other countries are allowed. Thus with the current reforms in the area of foreign direct investment, it shall boost the economic growth of the Saudi economy. In line with foreign direct investment, financial development is also central to stimulate the economic growth of the economies (Levine, 2005; Demirguc -kunt and Levine, 2008). Studies related to Saudi economy manifest the significance of the financial development on the economic growth of the economy (Ibrahim, 2013; Samargandi, Fidrmuc and Ghosh, 2013). In the Saudi economy, banks are professionally managed and regulated by SAMA, which per se has strongly taken care of the risk related to financial domain. Further the capital market in Saudi Arabia has gone through 
multiple reforms so as to attract capital inflows from foreign investors. The Saudi vision 2030 aims to enhance the foreign direct investment from the present position of 3.8 percent to 5.7 percent in 2030 and assist in escalating the GDP size (rank wise) from $19^{\text {th }}$ to $15^{\text {th }}$ in the global economy by the stipulated time frame.

\section{Review of Literature}

Multiple studies have revealed that the escalated usage of FDI has been an important source to augment the economic growth of the economies. As a matter of fact, studies revealing the potent of FDI in enhancing the economic growth, further impart caution that the positive influence of FDI hinges on multiples pedestals including the development of the financial landscape of the economy (Blomstrom et al., 1992; Borensztein et al., 1998 and Alfaro et al., 2004).Thus it is pertinent to appreciate the facet of financial development. The importance of financial system on the economic growth is traced to the magisterial work of Bagehot, W. (1873) and Schumpeter, J. (1911). Of late, it has been reinforced by the study highlighting the fundamental contribution of the financial matrix in the growth of the economy (Levine 1997).Studies highlighting the importance of financial development in enhancing the economic growth of the economy are marked as supply leading hypothesis. These studies reveal that development of financial system shall escalate the economic growth. Thereby the pertinent related studies in form of McKinnon (1973), Shaw (1973), King and Levine (1993), Levine (1997), Rajan and Zingales (1998), Darrat, (1999), Hussain and Chakraborty (2012) unearth that advancement of the financial system is central input for the growth of the economy. The importance of banking sector and stock market is pertinent for the financial development and economic growth of the economies (Standley, 2010; Shahbaz et al., 2008).

The performance of the FDI has been more confirming and positive on the landscape of the developing economies than to the developed world. FDI encompasses not only the channelization of capital, but covers multiple modes in the manifestation of technology and expertise skills. Likewise, the economic growth is goaded by multiple local and global ingredients covering the external investment. Over the preceding few decenniums, there have been substantial investigation on the linkage between the foreign direct investment and economic growth. Selected researches report that the potent of foreign direct investment have positively driven the growth of the developing economies (Bloomstorm et al. 1992; Borensztein et al 1998). Gupta \& Singh (2016) investigates the linkage between foreign direct investment (FDI) and economic growth (GDP) for Brazil, Russia, India, China and South Africa (BRICS nations) individually for the time period 1992-2013. The study revealed the existence of one way GDP led FDI causality for Brazil, India and China, whereas there is no linkage between the purported variables for Russia and South Africa. Basu, Chakraborty \& Reagle (2003) through the fabric of panel cointegration, investigates the linkage between FDI and growth for a set of twenty three developing economies. The study manifest two way relationship between the stipulated variables in the unfasten economies, whereas causality run unidirectional from GDP to FDI in the tightened economies. Trevino, et al., (2003) through the pooled data from 1990-99 gauged the role of foreign aids and FDI in the five developing economies. The study reported that the positive influence of FDI is more than the foreign aids in comparatively open regimes. Borensztein et al. (1998) through the usage of data from sixty nine economies revealed that FDI is a pertinent mode to enhance the economic growth. The study unfolds that the FDI inflows extend the technology to the economies, which has more potent than the internal investment. Chowdhury and Mavrotas (2006) investigate the linkage between FDI and economic growth among the three developing countries -Chile, Malaysia and Thailand from 1969 to 2000.The study employed the Toda-Yamamoto test for causality. The study revealed that GDP leads FDI in Chile, whereas there is bi-directional causality between GDP and FDI in the case of Malaysia and Thailand. Wang and Wong (2009) investigate the relation of foreign direct investment on economic growth through the data of 84 economies from 1987 to 2001 . The study makes an endeavor to unfold the varied growth potent of multifarious FDI modes. The study splits the FDI inflows into greenfield and M\&As, thereby gauges the effect on the economic growth. The study advocates the green field investment drive the economic growth, whereas the potent of M\&As can be garnered through matched level of human capital. de Vita and Kyaw (2009) through the substantial data set of 126 developing countries revealed that positive result of FDI and portfolio investment can be achieved, provided that adequate pedestal of economic development exists in the developing economies. Choe (2003) exhibits the linkage between economic growth and FDI in eighty economies for the time period 1971-95 through the employment of a panel VAR model. The study put forward robust favorable linkage between economic growth and FDI inflows.

Few studies manifest implausible relationship between the FDI and economic growth. In this very vein, studies brought by Griffin (1970), Mansfield and Romeo (1980), Saltz (1992) and Bacic, et al., 2005 manifest resembling conclusion. Bagli \& Adhikary (2014) manifest that openness and growth of FDI inflow is insignificant in the assessment of the growth of Indian economy. Nair-Reichert and Weinhold (2001) employed a mixed fixed and random (MFR) panel data estimation to gauge the linkage between the FDI and the economic growth. The study 
revealed that the linkage between the investment and the economic growth is extremely varied in the sphere of the developing economies. Sarkar (2007) employed panel data analysis to shed apprehension on the linkage between the purported variables. The study indicates that there is no long term linkage between FDI share and growth regardless of the characteristic of economies, in terms of closed or open and poor or rich. De Mello (1999) employed time series and panel data for selected OECD and non-OECD economies for the time span 1970 to 1990 to study FDI led growth. The study concludes that in the case of non-OECD countries, the benefits of FDI led growth are less on account of multiple country specific factors. Irandoust (2001) examines FDI led growth for Denmark, Finland, Norway, and Sweden through the framework of a vector autoregression (VAR) model. The study revealed mixed results for the purported variables. On one hand it unfolds casual relation for Norway and Sweden, whereas the study exhibits no relationship for Finland and Denmark. Haddad \& Harrison (1993) through a unique firm level data frame, make an endeavor to investigate the positive spillover effect of foreign investment in the Moroccan manufacturing sector. The study turns down the possibility that foreign investment shall increase the growth in the economy.

Selected research works highlight that the economies having well carved financial structure \&markets are central in stimulating the favorable potent of external investment on the growth of the economies (Hermes and Lensink, 2003and Alfaro et al. 2004). Azman-Saini et al. (2010) demonstrate the importance of financial development in enhancing the positive influence of FDI on growth through the usage of data from 91 economies over the period 1975 to 2005. The study reveals that favorable impact of FDI hinges on the pedestal of development of the financial markets. The policies formulation for FDI and financial development should be made hand in hand. Adeniyi, O. et al., (2012) investigates through a trivariate framework, the relationship between foreign direct investment (FDI), economic growth and financial development for selected African countries for the period 1970-2005.The study reveals the role of financial development for garnering the gains of FDI on the economic growth in Ghana, Gambia and Sierralone, further there is no trace of linkage in the case of the Nigerian economy. Choong \& Lam (2011) employed Generalized Method of Moments (GMM) panel data analysis to investigate the linkage between FDI, financial development and economic growth in the data set of 70 countries encompassing developed and developing economies from 1988 to 2002. The study revealed that influence of FDI on economic growth is double edged. The study endorses the current insights that specific quantum of financial development is fundamental to fetch the gains of FDI inflows on the growth of the economies. Sghaier \& Abida (2013) employed GMM panel data analysis to investigate the relationship between FDI and economic growth in panel set of four economies of North Africa (Tunisia, Morocco, Algeria and Egypt) over the time period 1980-2011. The study reveals favorable linkage between FDI and economic growth. Further the study reveals that advancement of internal financial framework is central for enabling the FDI inflows to have favorable impact on economic growth. Shahbaz \& Rahman (2012) made use of ARDL and VECM to examine the influence of financial development, imports and foreign direct investment (FDI) on economic growth in case of Pakistan over the period of 1990-2008. The study revealed long term positive linkage among the stipulated variables in the economy. Choong, C. K. (2012) investigates the linkage between FDI, financial development and economic growth in a data set of 95 countries encompassing developed and developing economies from 1983 to 2006. Through the usage of GMM panel data analysis, the study revealed favorable linkage between FDI inflows and economy growth. The study highlights the importance of reform in the financial system at the domestic level so as to enhance the economic growth through the FDI inflows. Nwosa, Agbeluyi, \& Saibu (2011) investigate the linkage among the financial development, foreign direct investment and economic growth in Nigeria over the time period 1970 to 2009 . Through the tri-variate vector error correction model, it is deduced that there is existence of causality among the financial development, foreign investment and economic growth. Further the purported variables have positive effect on the growth of the economy. Lee \& Chang (2009) employed contemporary development in panel counteraction and panel error correction models for a data frame of thirty seven economies for the time period 1970-2002. The study brought concrete manifestation of long run linkage among the FDI, financial development and economic growth. The study reiterates the importance of financial development in order to fetch the expected yield linked with FDI inflows. Anwar \& Sun (2011) employed GMM model to investigate the linkage among the economic growth, the stock of foreign investment and the stock of domestic capital in Malaysia for the time span 1970 to 2007. The study reports that an enhancement in the stock of foreign investment in Malaysia has led to an enhancement in the stock of domestic capital and economic growth. Further the stock of foreign investment hinges on quantum of liberalization of the economy in tandem with the real exchange rate. Hermes \& Lensink (2003) underscore the role of financial development as prerequisite for garnering the gains of FDI inflows on the economic growth. The study covering sixty seven countries make an endeavor to examine the contribution of financial development in strengthening the linkage between FDI and economic growth. The study reports that out of the data set, thirty seven economies have adequate financial framework that stimulate FDI to assist favorably to the economic growth. 


\section{Data and Methodology}

\subsection{Data and Variables}

This study investigates the linkage among foreign direct investment, financial development and economic growth in Saudi Arabian context from 1970 to 2015. The data is taken from various sources which include International Monetary Fund (IMF) data bank, International Financial Statistics databases, World Bank data set for countries and World Bank GDP estimates. The study has taken GDP per Capita as an indicator for economic growth on account of the fact that it is primarily taken as indicator to measure the growth of economies in the literature. In the lexicon of World Bank, the term Foreign Direct Investment (FDI) is stated in the following manner as "the net inflows of investment to acquire a lasting management interest (10 percent or more of voting stock) in an enterprise operating in an economy other than that of the investor. It is the sum of equity capital, reinvestment of earnings, other long-term capital, and short-term capital as shown in the balance of payments. This series reveals net inflows (new investment inflows less disinvestment) in the reporting economy from foreign investors, and is divided by GDP". In this very vein, the current paper takes in to consideration to gauge the FDI in Saudi Arabian perspective, where the FDI is manifested as a percentage of GDP. As multiples studies have taken Broad Money (M2) as a pointer for financial development. Likewise it is applied in the current study to gauge the financial development.

\subsection{Augmented Dickey-Fuller (ADF) Test}

In order to ascertain the stationary trend of data, unit root tests are employed as these tests assist to avoid specious results due to non-stationarity of data that can disqualify other statistical tests. The study has employed the Augmented Dickey-Fuller test (ADF) test to check the integrated order and behavior of the time series data. The general econometric expression of ADF having a constant and trend is given below.

$$
\Delta \mathrm{Yt}=\lambda 0+\lambda 1 \mathrm{t}+\lambda 2 \mathrm{yt}-1+\sum_{\mathrm{i}=1}^{\mathrm{n}-1} \lambda \mathrm{i} \Delta \mathrm{Yt}-1+\mathrm{et}
$$

The Equation represents variables in the form of $\Delta \mathrm{Yt}$ in a time period $\mathrm{t}$, while $\lambda 0$ is a constant term and $\Delta \mathrm{Yt}=\mathrm{Yt}$ -Yt-1 where $t$ represent the trend and et is noise error term used in the model.

Table 1. ADF Unit Root Test

\begin{tabular}{|c|c|c|c|c|c|c|c|c|}
\hline \multirow[t]{3}{*}{ VARIABLES } & \multicolumn{4}{|c|}{ At level } & \multicolumn{4}{|c|}{ At first difference } \\
\hline & \multicolumn{2}{|c|}{ With constant } & \multicolumn{2}{|c|}{$\begin{array}{l}\text { With constant linear } \\
\text { trend }\end{array}$} & \multicolumn{2}{|c|}{ CONSTANT } & \multicolumn{2}{|c|}{$\begin{array}{l}\text { With COSTANT } \\
\text { LINEAR TREND }\end{array}$} \\
\hline & t-stat & C- VALUE & t-stat & C- VALUE & t-stat & C- VALUE & t-stat & C- VALUE \\
\hline GDP & -1.675 & -3.588 & -2.081 & -4.180 & -4.575 & -3.588 & -4.463 & -4.180 \\
\hline FDI & -3.535 & --3.588 & -3.865 & -4.180 & -8.456 & -3.588 & -8.365 & -4.180 \\
\hline FD & -.571 & --3.588 & -2.046 & --4.180 & -5.867 & -3.588 & -5.796 & -4.180 \\
\hline
\end{tabular}

The results revealed in the above table one reports that the data used for this study are statistically valid as the critical values are more than the $\mathrm{t}$ statistics values at level with constant and with the constant linear trend. It manifest that the data is non stationary at level. While the $t$ statistic values are greater than the critical values at first difference with constant and with the constant linear trend that reports that the data are stationary at first difference, thus after addressing the case of unit root, one can go ahead to employ the further tests to ascertain the co integration.

\subsection{Lag Length Selection}

As the VAR model is sensitive to the lag length so the study has utilized the lag length selection yardstick. The majority of the test for lag length selection recommends the lag length 2 as given in the below mentioned table. So the lag length selected for Vector Auto Regression Model (VAR) is 2. This lag length will be applied for other tests as well.

Table 2. Selection of Lag length

\begin{tabular}{lllll}
\hline & & & & \\
& & FPE: Final & AIC :Akaike SC :Schwarz Hannan-Quinn \\
prediction & $\begin{array}{l}\text { Anformation information information } \\
\text { criterion }\end{array}$ & criterion & criterion \\
\hline
\end{tabular}




\begin{tabular}{lllllll}
\hline 0 & -697.4566 & $\mathrm{NA}$ & $6.14 \mathrm{e}+10$ & 33.35508 & 33.47920 & 33.40057 \\
\hline 1 & -571.6513 & 227.6476 & $2.36 \mathrm{e}+08$ & 27.79292 & $28.28940^{*}$ & 27.97490 \\
\hline 2 & -559.4051 & $20.41038^{*}$ & $2.04 \mathrm{e}+08 *$ & $27.63834 *$ & 28.50717 & $27.95680^{*}$ \\
\hline 3 & -555.6354 & 5.744344 & $2.67 \mathrm{e}+08$ & 27.88740 & 29.12859 & 28.34234 \\
\hline 4 & -550.2256 & 7.470583 & $3.28 \mathrm{e}+08$ & 28.05836 & 29.67191 & 28.64979 \\
\hline
\end{tabular}

* indicates lag order selected by the criterion

LR: sequential modified LR test statistic (each test at 5\% level)

\subsection{Test for Co-integration}

This research paper has employed Johansen and Jueslius (1990) procedure to test for the co-integration among the variables taken under study. The below mentioned tables reveal that Trace test and Max-eigen values are lower than the critical values and the $\mathrm{p}$ values for them are also insignificant. It reveals that there is no co integrated equation for the variables. So there is no long run relationship among the variables under consideration. Thus the Vector Error Correction Model (VECM) is not pertinent in the current study.

Table 3. Unrestricted Co-integration Rank Test (Trace)

\begin{tabular}{lcccc}
\hline Hypothesized & & Trace & 0.05 & \\
\hline No. of CE(s) & Eigenvalue & Statistic & Critical Value & Prob.** \\
\hline None & 0.196165 & 19.45627 & 29.79707 & 0.4605 \\
\hline At most 1 & 0.166941 & 9.848373 & 15.49471 & 0.2926 \\
\hline At most 2 & 0.040340 & 1.811757 & 3.841466 & 0.1783 \\
\hline
\end{tabular}

Trace test indicates no co-integration at the 0.05 level

* denotes rejection of the hypothesis at the 0.05 level

**MacKinnon-Haug-Michelis (1999) p-values

Table 4. Unrestricted Cointegration Rank Test (Maximum Eigenvalue)

\begin{tabular}{lllll} 
Hypothesized & \multicolumn{3}{l}{ Max-Eigen } & 0.05 \\
\hline No. of CE(s) & Eigenvalue & Statistic & Critical Value & Prob.** \\
\hline \hline None & 0.196165 & 9.607902 & 21.13162 & 0.7806 \\
\hline At most 1 & 0.166941 & 8.036616 & 14.26460 & 0.3750 \\
\hline At most 2 & 0.040340 & 1.811757 & 3.841466 & 0.1783
\end{tabular}

Max-eigenvalue test indicates no cointegration at the 0.05 level

* denotes rejection of the hypothesis at the 0.05 level

**MacKinnon-Haug-Michelis (1999) p-values

\subsection{Unrestricted Vector Auto-regression (VAR)}

On account of non-significant co integrating equations, the unrestricted vector auto -regression (VAR) is applied to ascertain the linkages. Vector auto regression (VAR) is an economic model that is employed for the comprehending of the linear linkage among the purported variables with multiple time series. VAR facilitate the auto regressive models by letting the impact for more than one changing variable on relevant time series data. The model considers all the variables as endogenous so distinct equation is developed for each variable considered under the study. Every equation covers lagged values of all the variables as dependent variables including the dependent variables itself. The basic equation in the reduced form is provided below.

$$
\begin{aligned}
\mathrm{GDP}_{\mathrm{t}, 1} & =\alpha_{1}+\varphi_{11} \mathrm{GDP}_{\mathrm{t}-1,1}+\varphi_{12} \mathrm{FDI}_{\mathrm{t}-1,2}+\varphi_{13} \mathrm{FD}_{\mathrm{t}-1,3}+\mathrm{w}_{\mathrm{t}, 1} \\
\mathrm{FDI}_{\mathrm{t}, 2} & =\alpha_{2}+\varphi_{21} \mathrm{FDI}_{\mathrm{t}-1,1}+\varphi_{22} \mathrm{GDP}_{\mathrm{t}-1,2}+\varphi_{23} \mathrm{FD}_{\mathrm{t}-1,3}+\mathrm{w}_{\mathrm{t}, 2} \\
\mathrm{FD}_{\mathrm{t}, 3} & =\alpha_{3}+\varphi_{31} \mathrm{FD}_{-1,1}+\varphi_{32} \mathrm{GDP}_{\mathrm{t}-1,2}+\varphi_{33} \mathrm{FDI}_{\mathrm{t}-1,3}+\mathrm{w}_{\mathrm{t}, 3}
\end{aligned}
$$


Following equations contain lagged values of three variables as the dependent. The basic equations used for Modified VAR are as under:

Equation: GDP $=\mathrm{C}(1) * \mathrm{GDP}(-1)+\mathrm{C}(2) * \mathrm{GDP}(-2)+\mathrm{C}(3) * \mathrm{FDI}(-1)+\mathrm{C}(4) * \mathrm{FDI}(-2)+\mathrm{C}(5) * \mathrm{FD}(-1)+\mathrm{C}(6) * \mathrm{FD}$ $(-2)+\mathrm{C}(7)$

Equation: $\mathrm{FDI}=\mathrm{C}(8) * \mathrm{GDP}(-1)+\mathrm{C}(9) * \mathrm{GDP}(-2)+\mathrm{C}(10) * \mathrm{FDI}(-1)+\mathrm{C}(11) * \mathrm{FDI}(-2)+\mathrm{C}(12) * \mathrm{FD}(-1)+\mathrm{C}(13) * \mathrm{FD}(-2)$ $+\mathrm{C}(14)$

Equation: $\mathrm{FD}=\mathrm{C}(15) * \mathrm{GDP}(-1)+\mathrm{C}(16) * \mathrm{GDP}(-2)+\mathrm{C}(17) * \mathrm{FDI}(-1)+\mathrm{C}(18) * \mathrm{FDI}(-2)+\mathrm{C}(19) * \mathrm{FD}(-1)+$ $\mathrm{C}(20) * \mathrm{FD}(-2)+\mathrm{C}(21)$

The table below shows results of VAR where there are few significant values of coefficients which suggest that there can be a relationship among the variables. Specifically the values of coefficients of economic growth are significant for C (1) and C (2) while it is significant in the case of FD for C (10) and for FDI its significant for (19).

Table 5. Vector Auto regression Estimates

\begin{tabular}{|c|c|c|c|}
\hline \multicolumn{4}{|c|}{ Standard errors in ( ) \& t-statistics in [ ] } \\
\hline & GDP & FDI & FD \\
\hline \multirow[t]{3}{*}{ GDP(-1) } & 1.524379 & 0.000581 & -0.000187 \\
\hline & $(0.27367)$ & $(0.00035)$ & $(0.00073)$ \\
\hline & {$[5.57010]$} & [ 1.63729] & {$[-0.25637]$} \\
\hline \multirow[t]{3}{*}{ GDP(-2) } & -0.699601 & -0.000460 & 0.000683 \\
\hline & $(0.31005)$ & $(0.00040)$ & $(0.00082)$ \\
\hline & {$[-2.25640]$} & {$[-1.14386]$} & [ 0.82896] \\
\hline \multirow[t]{3}{*}{ FDI(-1) } & 41.17453 & 0.530061 & 0.080874 \\
\hline & $(131.616)$ & $(0.17067)$ & $(0.34993)$ \\
\hline & {$[0.31284]$} & [3.10581] & {$[0.23111]$} \\
\hline \multirow[t]{3}{*}{ FDI(-2) } & 158.3707 & -0.031685 & -0.311924 \\
\hline & $(118.241)$ & $(0.15332)$ & $(0.31437)$ \\
\hline & [ 1.33938$]$ & {$[-0.20665]$} & {$[-0.99221]$} \\
\hline \multirow[t]{3}{*}{$\mathrm{FD}(-1)$} & 107.0279 & 0.021240 & 0.802401 \\
\hline & $(107.399)$ & $(0.13927)$ & $(0.28555)$ \\
\hline & {$[0.99654]$} & {$[0.15251]$} & [ 2.81004] \\
\hline \multirow[t]{3}{*}{$\mathrm{FD}(-2)$} & -90.79128 & -0.024795 & 0.102421 \\
\hline & (101.203) & $(0.13123)$ & $(0.26907)$ \\
\hline & {$[-0.89712]$} & {$[-0.18894]$} & [ 0.38064$]$ \\
\hline \multirow[t]{3}{*}{$\mathrm{C}$} & 977.1889 & -0.776699 & 0.569910 \\
\hline & $(872.492)$ & $(1.13137)$ & $(2.31974)$ \\
\hline & [1.12000] & {$[-0.68651]$} & [ 0.24568$]$ \\
\hline R-squared & 0.915126 & 0.451585 & 0.921688 \\
\hline Adj. R-squared & 0.901363 & 0.362653 & 0.908989 \\
\hline Sum sq. resids & $1.32 \mathrm{E}+08$ & 221.5263 & 931.3190 \\
\hline S.E. equation & 1886.993 & 2.446875 & 5.017049 \\
\hline F-statistic & 66.49014 & 5.077868 & 72.57859 \\
\hline
\end{tabular}




\begin{tabular}{lrrr} 
Log likelihood & -390.5019 & -97.99303 & -129.5864 \\
Akaike AIC & 18.06827 & 4.772411 & 6.208471 \\
Schwarz SC & 18.35212 & 5.056259 & 6.492319 \\
Mean dependent & 11173.79 & 1.248967 & 40.56013 \\
S.D. dependent & 6008.275 & 3.064954 & 16.63037 \\
\hline \hline Determinant resid covariance (dof adj.) & $1.26 \mathrm{E}+08$ & \\
Determinant resid covariance & 74681845 & \\
Log likelihood & -586.1323 & \\
Akaike information criterion & 27.59692 & \\
Schwarz criterion & 28.44847 &
\end{tabular}

Table 6. Total system (balanced) observations 132

\begin{tabular}{rrrrr}
\hline & Coefficient & Std. Error & t-Statistic & Prob. \\
\hline $\mathrm{C}(1)$ & 1.524379 & 0.273672 & 5.570097 & 0.0000 \\
\hline $\mathrm{C}(2)$ & -0.699601 & 0.310051 & -2.256404 & 0.0260 \\
\hline $\mathrm{C}(3)$ & 41.17453 & 131.6160 & 0.312838 & 0.7550 \\
\hline $\mathrm{C}(4)$ & 158.3707 & 118.2414 & 1.339385 & 0.1832 \\
\hline $\mathrm{C}(5)$ & 107.0279 & 107.3992 & 0.996542 & 0.3212 \\
\hline $\mathrm{C}(6)$ & -90.79128 & 101.2034 & -0.897117 & 0.3716 \\
\hline $\mathrm{C}(7)$ & 977.1889 & 872.4921 & 1.119997 & 0.2651 \\
\hline $\mathrm{C}(8)$ & 0.000581 & 0.000355 & 1.637290 & 0.1044 \\
\hline $\mathrm{C}(9)$ & -0.000460 & 0.000402 & -1.143858 & 0.2551 \\
\hline $\mathrm{C}(10)$ & 0.530061 & 0.170667 & 3.105813 & 0.0024 \\
\hline $\mathrm{C}(11)$ & -0.031685 & 0.153324 & -0.206655 & 0.8367 \\
\hline $\mathrm{C}(12)$ & 0.021240 & 0.139265 & 0.152513 & 0.8791 \\
\hline $\mathrm{C}(13)$ & -0.024795 & 0.131231 & -0.188938 & 0.8505 \\
\hline $\mathrm{C}(14)$ & -0.776699 & 1.131366 & -0.686514 & 0.4938 \\
\hline $\mathrm{C}(15)$ & -0.000187 & 0.000728 & -0.256368 & 0.7981 \\
\hline $\mathrm{C}(16)$ & 0.000683 & 0.000824 & 0.828958 & 0.4089 \\
\hline $\mathrm{C}(17)$ & 0.080874 & 0.349935 & 0.231112 & 0.8177 \\
\hline $\mathrm{C}(18)$ & -0.311924 & 0.314375 & -0.992205 & 0.3233 \\
\hline $\mathrm{C}(19)$ & 0.802401 & 0.285548 & 2.810037 & 0.0059 \\
\hline $\mathrm{C}(20)$ & 0.102421 & 0.269075 & 0.380642 & 0.7042 \\
\hline $\mathrm{C}(21)$ & 0.569910 & 2.319742 & 0.245678 & 0.8064 \\
\hline & & & &
\end{tabular}

\subsection{Granger Causality Test}

In order to determine the causal relationship and direction of causality among the variables the Granger causality test has been applied in the paper. The purported test along with the stipulated variables can be modelled in the following basic mode. 


$$
\begin{aligned}
& \mathrm{GDP}_{\mathrm{t}}=\alpha_{0}+\sum_{\mathrm{i}=1}^{\mathrm{n}} \alpha_{1 \mathrm{i}} \mathrm{GDP}_{\mathrm{t}-\mathrm{i}}+\sum_{\mathrm{i}=1}^{\mathrm{n}} \alpha_{2 \mathrm{i}} \mathrm{FDI}_{\mathrm{t}-\mathrm{i}}+\sum_{\mathrm{i}=1}^{\mathrm{n}} \alpha_{3 \mathrm{i}} \mathrm{FD}_{\mathrm{t}-\mathrm{i}}+\alpha_{4} \mathrm{ECT}_{\mathrm{t}-1}+\emptyset_{\mathrm{t}} \\
& \mathrm{FDI}_{\mathrm{t}}=\beta_{0}+\sum_{\mathrm{i}=1}^{n} \beta_{1 \mathrm{i}} \mathrm{GDP}_{\mathrm{t}-\mathrm{i}}+\sum_{\mathrm{i}=1}^{\mathrm{n}} \beta_{2 \mathrm{i}} \mathrm{FDI}_{\mathrm{t}-\mathrm{i}}+\sum_{\mathrm{i}=1}^{\mathrm{n}} \alpha_{3 \mathrm{i}} \mathrm{FD}_{\mathrm{t}-\mathrm{i}}+\beta_{4} \mathrm{ECT}_{\mathrm{t}-1}+\theta_{\mathrm{t}} \\
& \mathrm{FD}_{\mathrm{t}}=\Psi_{0}+\sum_{\mathrm{i}=1}^{\mathrm{n}} \psi_{1 \mathrm{i}} \mathrm{GDP}_{\mathrm{t}-\mathrm{i}}+\sum_{\mathrm{i}=1}^{\mathrm{n}} \Psi_{2 \mathrm{i}} \mathrm{FDI}_{\mathrm{t}-\mathrm{i}}+\sum_{\mathrm{i}=1}^{\mathrm{n}} \Psi_{3 \mathrm{i}} \mathrm{FD}_{\mathrm{t}-\mathrm{i}}+\psi_{4} \mathrm{ECT}_{\mathrm{t}-1}+\mathrm{\Pi}_{\mathrm{t}}
\end{aligned}
$$

Where $\mathrm{ECT}_{\mathrm{t}-1}$ is error correction term at lag order one and $\emptyset, \theta$ and $\Pi$ are white noise residual and $\alpha_{0,} \beta_{0}, \psi_{0}$ are the intercepts in the above model. The results obtained from the table seven shows the significant facts; first the economic growth measured by GDP per Capita causes the Foreign Direct Investment (FDI), Secondly the economic growth also causes financial development (FD). No Causality is found between Foreign Direct Investment (FDI) and financial development FD.

Table 7. Pairwise Granger Causality Tests

Sample: 19702015

Lags: 2

\begin{tabular}{lccc}
\hline \hline Null Hypothesis: & Obs & F-Statistic & Prob. \\
\hline \hline FDI does not Granger Cause GDP & 44 & 1.44679 & 0.2477 \\
GDP does not Granger Cause FDI & & 5.19576 & 0.0100 \\
\hline \hline FD does not Granger Cause GDP & \multirow{2}{*}{44} & 0.75460 & 0.4769 \\
GDP does not Granger Cause FD & & 4.33232 & 0.0200 \\
\hline \hline FD does not Granger Cause FDI & \multirow{2}{*}{44} & 1.18693 & 0.3159 \\
FDI does not Granger Cause FD & & 0.88513 & 0.4208 \\
\hline \hline
\end{tabular}

\subsection{The Impulse Response Function}

Impulse response function is applied to gauge the impact of the shock to the provided variables. Impulse response function manifest the power of a one-time shock to one of the variation on the current and future values of all the endogenous variables under consideration. The mentioned figures reveal the outcome of impulse response on each variables in the form of $3 \times 3$ graphs. 

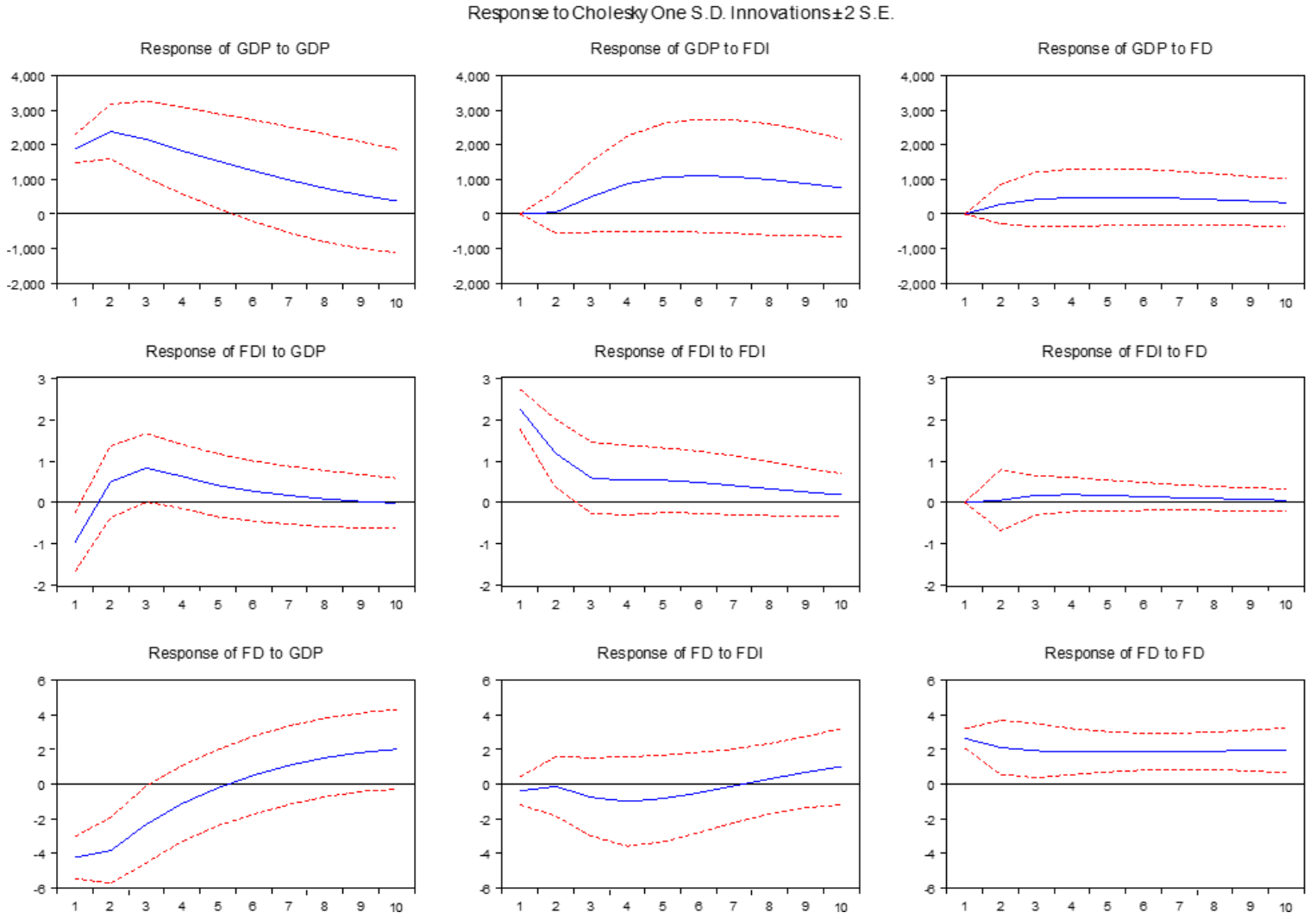

The above graphs reveal the response of GDP (economic growth) to a shock related with itself and other variable FDI and FD. It is manifested that the response of GDP to itself is a negative change in GDP while in case of Financial Depth and foreign direct investment the response is mostly stable. Response to the shock is positive but FD to GDP while other reaction is generally stable.

\subsection{Variance Decomposition Method}

It is applied for the analysis of a VAR model once it has been tailored. This is a tool to inspect the system dynamics. This method decomposes the variation in an endogenous variable into the component shocks in regard to additional selected variables in the stipulated setup. The significance of the model is on account of reporting about the specific random innovations to the variables in the stipulated setup.

Tables 8, 9 \& 10. Variance decomposition of variables

GDP

\begin{tabular}{lllll}
\hline Period & S.E. & GDP & FDI & FD \\
\hline 1 & 1886.993 & 100.0000 & 0.000000 & 0.000000 \\
\hline 2 & 3052.514 & 99.11526 & 0.027851 & 0.856889 \\
\hline 3 & 3793.151 & 96.43470 & 1.783890 & 1.781411 \\
\hline 4 & 4326.867 & 91.97853 & 5.462075 & 2.559399 \\
\hline 5 & 4735.118 & 87.24441 & 9.561486 & 3.194101 \\
\hline 6 & 5043.633 & 83.02035 & 13.26473 & 3.714921 \\
\hline 7 & 5269.927 & 79.52249 & 16.33705 & 4.140460 \\
\hline 8 & 5430.848 & 76.76436 & 18.75131 & 4.484336 \\
\hline 9 & 5541.823 & 74.68207 & 20.55877 & 4.759158 \\
\hline 10 & 5616.096 & 73.17388 & 21.84954 & 4.976582 \\
\hline
\end{tabular}


Table: FDI

\begin{tabular}{lllll}
\hline Period & S.E. & GDP & FDI & FD \\
\hline 1 & 2.446875 & 15.48028 & 84.51972 & 0.000000 \\
\hline 2 & 2.763755 & 15.35296 & 84.60587 & 0.041167 \\
\hline 3 & 2.952039 & 21.42793 & 78.19082 & 0.381257 \\
\hline 4 & 3.070845 & 23.98109 & 75.27328 & 0.745628 \\
\hline 5 & 3.149361 & 24.51440 & 74.48613 & 0.999470 \\
\hline 6 & 3.201540 & 24.43227 & 74.40182 & 1.165906 \\
\hline 7 & 3.234124 & 24.21131 & 74.51314 & 1.275547 \\
\hline 8 & 3.253320 & 23.99974 & 74.65472 & 1.345538 \\
\hline 9 & 3.264110 & 23.84862 & 74.76379 & 1.387583 \\
\hline 10 & 3.269942 & 23.76555 & 74.82341 & 1.411039 \\
\hline
\end{tabular}

Table: FD

\begin{tabular}{lllll}
\hline Period & S.E. & GDP & FDI & FD \\
\hline 1 & 5.017049 & 71.70581 & 0.602524 & 27.69166 \\
\hline 2 & 6.664218 & 73.82079 & 0.379865 & 25.79935 \\
\hline 3 & 7.356089 & 70.61897 & 1.379365 & 28.00166 \\
\hline 4 & 7.738323 & 65.92412 & 2.929372 & 31.14651 \\
\hline 5 & 8.005924 & 61.66543 & 3.848087 & 34.48648 \\
\hline 6 & 8.252156 & 58.42403 & 3.992377 & 37.58359 \\
\hline 7 & 8.537074 & 56.23092 & 3.744393 & 40.02469 \\
\hline 8 & 8.887333 & 54.84540 & 3.572922 & 41.58168 \\
\hline 9 & 9.302078 & 53.91807 & 3.802502 & 42.27943 \\
\hline 10 & 9.764054 & 53.15269 & 4.530404 & 42.31690 \\
\hline
\end{tabular}

From the above mention tables, it is manifested that 22 percent of GDP can be disclosed by the effects of FDI, whereas it is about 5 percent for the FD. On the other side, 24 percent of FDI can be manifested through the variation in GDP, while it is 1.4 percent with regard to the effect of FD on FDI. In regard to FD, it is manifested that FD are formed upto 53 percent by the effects of GDP and it is only 5 percent in the case of FDI.

\section{Conclusion}

This research is an endeavor in order to illuminate and form a link among foreign direct investment, financial development and economic growth in Saudi Arabia for the span covering from 1970 to 2015 by employing modified Granger casualty model. As the outcome of Johansen co-integration test illustrates, no long run co-integration can be recognized among foreign direct investment, financial development and economic growth. VAR model has been applied to gauge the linkage, while the outcome of which demonstrates that there is a link between economic growth, financial development and foreign direct investment. The Granger causality test also confirms that economic growth causes foreign direct investment and financial development which is a unidirectional causality running from economic growth towards foreign direct investment and financial development. No significant causality can be observed empirically between foreign direct investment and financial development. This feature can be attributed to the fact that Saudi Arabian economy is still substantially dependent on its hydrocarbon resources which is the driving force behind the growth. The effect of foreign direct investment is not significant due to fact the economy is still a closed economy, where liberalization measures are still at initial stage. The government has launched Vision 2030 in order to reduce its dependency on oil resources which is expected to leverage the foreign direct investment and financial development, which can eventually have considerable effect on the economic growth. Another reason for the insignificant causality between FDI and economic growth is partly due to equity restrictions. This vision 2030 is expected to enhance the foreign direct investment and financial development in the ensuing years. Thus future research studies in this direction are required in identical economies to substantiate the result of the current study. 


\section{Acknowledgment}

The authors would like to thank the Deanship of Scientific Research at King Saud University represented by the Research Center at CBA for supporting this research financially.

\section{References}

Adeniyi, O., Omisakin, O., Egwaikhide, F. O., \& Oyinlola, A. (2012). Foreign direct investment, economic growth and financial sector development in small open developing economies. Economic Analysis and Policy, 42(1), 105-127. https://doi.org/10.1016/S0313-5926(12)50008-1

Agarwal, S. (2001). Stock market development and economic growth: preliminary evidence from African countries. Journal of Sustainable Development in Africa.

Almfraji, M. A., \& Almsafir, M. K. (2014). Foreign Direct Investment and Economic Growth Literature Review from 1994 to 2012. Procedia-Social and Behavioral Sciences, 129, 206-213.

Anwar, S., \& Sun, S. (2011). Financial development, foreign investment and economic growth in Malaysia. Journal of Asian Economics, 22(4), 335-342. https://doi.org/10.1016/j.asieco.2011.04.001

Axarloglou, K., \& Pournarakis, M. (2007). Do all foreign direct investment inflows benefit the local economy?. The World Economy, 30(3), 424-445. https://doi.org/10.1111/j.1467-9701.2006.00824.x

Azman-Saini, W. N. W., Law, S. H., \& Ahmad, A. H. (2010). FDI and economic growth: New evidence on the role of financial markets. Economics letters, 107(2), 211-213. https://doi.org/10.1016/j.econlet.2010.01.027

Bacic, K., Racic, D., \& Ahec-Sonje, A. (2004). The effects of FDI on recipient countries in Central and Eastern Europe. Privredna kretanja i ekonomska politika, 14(100), 58-96.

Bagehot, W. (1873). Lombart street: A Description of the money market. New York, Wiley \& Sons

Bagli, S., \& Adhikary, M. (2014). FDI inflow and economic growth in India an empirical analysis. Economic Affairs, 59(1), 23. https://doi.org/10.5958/j.0976-4666.59.1.003

Balasubramanyam, V.N., Salisu, M.A., \& Sapsford, D. (1996). Foreign direct investment and Growth in EP and IS countries. Economics Journal, 106(434), 92-105. https://doi.org/10.2307/2234933

Basu, P., Chakraborty, C., \& Reagle, D. (2003). Liberalization, FDI, and growth in developing countries: A panel cointegration approach. Economic Inquiry, 41(3), 510-516. https://doi.org/10.1093/ei/cbg024

Blomstrom, M., Lipsey, R. E., \& Zejan, M. (1992). What explains developing country growth? (No. w4132). National bureau of economic research. https://doi.org/10.3386/w4132

Borensztein, E., De Gregorio, J., \& Lee, J. W. (1998). How does foreign direct investment affect economic growth?. Journal of international Economics, 45(1), 115-135. https://doi.org/10.1016/S0022-1996(97)00033-0

Choe, J. I. (2003). Do foreign direct investment and gross domestic investment promote economic growth? Review of Development Economics, 7(1), 44-57. https://doi.org/10.1111/1467-9361.00174

Choong, C. K. (2012). Does domestic financial development enhance the linkages between foreign direct investment and economic growth?. Empirical Economics, 42(3), 819-834. https://doi.org/10.1007/s00181-011-0455-2

Choong, C. K., \& Lam, S. Y. (2011). Foreign Direct Investment, Financial Development and Economic Growth: Panel Data Analysis. IUP Journal of Applied Economics, 10(2), 57.

Chowdhury, A., \& Mavrotas, G. (2006). FDI and growth: What causes what? The World Economy, 29(1), 9-19.

Darrat, A. F. (1999). Are financial deepening and economic growth casually related? Another look at the evidence. International Economic Journal, 13, 19-35.

De Mello, L. R. (1999). Foreign direct investment-led growth: evidence from time series and panel data. Oxford economic papers, 51(1), 133-151. https://doi.org/10.1093/oep/51.1.133

de Vita, G., \& Kyaw, K. S. (2009). Growth effects of FDI and portfolio investment flows to developing countries: a disaggregated analysis by income levels. Applied Economics Letters, 16(3), 277-283.

Demirguc-Kunt, A., \& R. Levine. (2008). Finance, Financial Sector Policies, and Long-Run Growth. Policy Research Working Paper 4469.

Griffin, K. (1970). Foreign capital, domestic savings and economic development. Bulletin of the Oxford University Institute of Economics \& Statistics, 32(2), 99-112. https://doi.org/10.1111/j.1468-0084.1970.mp32002002.x

Gupta, P., \& Singh, A. (2016). Causal nexus between foreign direct investment and economic growth: A study of BRICS nations using VECM and Granger causality test. Journal of Advances in Management Research, 13(2), 179-202. https://doi.org/10.1108/JAMR-04-2015-0028 
Haddad, M., \& Harrison, A. (1993). Are there positive spillovers from direct foreign investment? Evidence from panel data for Morocco. Journal of development economics, 42(1), 51-74.

Hermes, N., \& Lensink, R. (2003). Foreign direct investment, financial development and economic growth. The Journal of Development Studies, 40(1), 142-163. https://doi.org/10.1080/00220380412331293707

Hussain, F., \& Chakraborty, D. K. (2012). Causality between financial development and economic growth: evidence from an Indian State. The Romanian Economic Journal, 15(45), 27-48.

Ibrahim, M. A. (2013). Financial development and economic growth in Saudi Arabian economy. Applied Econometrics and International Development, 13(1), 133-144.

Irandoust, J. E. M. (2001). On the causality between foreign direct investment and output: a comparative study. The International Trade Journal, 15(1), 1-26. https://doi.org/10.1080/088539001300005431

King, R. G., \& Levine, R. (1993). Finance and growth: Schumpeter might be right. Quarterly Journal of Economics, 108(3), 717-737. https://doi.org/10.2307/2118406

Lee, C. C., \& Chang, C. P. (2009). FDI, financial development, and economic growth: international evidence. Journal of Applied Economics, 12(2), 249-271. https://doi.org/10.1016/S1514-0326(09)60015-5

Levine, R. (1997). Financial development and economic growth: views and agenda. Journal of Economic Literature, $35,688-726$.

Levine, R. (2005). Finance and growth: Theory and evidence. In P. Aghion and S. Durlaff (Eds.), Handbook of Economic Growth. The Netherlands: Elsevier Science.

Mansfield, E., \& Romeo, A. (1980). Technology transfer to overseas subsidiaries by US-based firms. The Quarterly Journal of Economics, 737-750. https://doi.org/10.2307/1885489

McKinnon, R. I. (1973). Money and Capital in Economic Development. Washington DC: The Brookings Institution.

Nair-Reichert, U., \& Weinhold, D. (2001). Causality Tests for Cross-Country Panels: a New Look at FDI and Economic Growth in Developing Countries. Oxford Bulletin of Economics and Statistics, 63(2), 153-171.

Nwosa, P. I., Agbeluyi, A. M., \& Saibu, O. M. (2011). Causal relationships between financial development, foreign direct investment and economic growth the case of Nigeria. International Journal of Business Administration, 2(4), 93. https://doi.org/10.5430/ijba.v2n4p93

Rajan, R. G., \& Zingales, L. (1998). Financial dependence and growth. American Economic Review, 88, 559-86.

Retrieved from https://tcdata360.worldbank.org/indicators/BX.KLT.DINV.WD.GD.ZS? country=BRA\&indicator=1541\&viz=li ne_chart\&years $=1970,2016$

Saltz, I. S. (1992). The negative correlation between foreign direct investment and economic growth in the third world: Theory and evidence. Rivista internazionale di scienze economiche e commerciali, 39(7), 617-633

Samargandi, N., Fidrmuc, J., \& Ghosh, S. (2014). Financial development and economic growth in an oil-rich economy: The case of Saudi Arabia. Economic Modelling, 43, 267-278.

Sarkar, P. (2007). Does Foreign Direct Investment promote growth? Panel data and time series evidence from Less Developed Countries, 1970-2002.

Schumpeter, J. A. (1911). The Theory of Economic Development. Harvard University Press, Cambridge, MA.

Sghaier, I. M., \& Abida, Z. (2013). Foreign direct investment, financial development and economic growth: Empirical evidence from North African Countries. Journal of International and Global Economic Studies, 6(1), 1-13.

Shahbaz, M., \& Rahman, M. M. (2012). The dynamic of financial development, imports, foreign direct investment and economic growth: cointegration and causality analysis in Pakistan. Global Business Review, 13(2), 201-219.

Shaw, E. S. (1973). Financial Deepening and Economic Development. New York: Oxford University Press.

United Nations Conference on Trade and Development. (1993). World investment report 1993.

United Nations Conference on Trade and Development. (1999). World investment report 1999.

United Nations Conference on Trade and Development. (2006). World investment report 2006: FDI from developing and transition economies: implications for development. UN.

Wang, M., \& Wong, S. (2009). What Drives Economic Growth? The Case of Cross-Border M\&A and Greenfield FDI Activities. Kyklos, 62(2), 316-330. https://doi.org/10.1111/j.1467-6435.2009.00438.x 